

\section{language teaching}

\section{surveys and studies}

The international research resource for language professionals

journals.cambridge.org/lta

Founding Editorial Team

Christopher Brumfit, John Higgins, Valerie Kinsella, George Perrin and John Trim

\section{Editor}

Graeme Porte, University of Granada, Spain

\section{Editorial Board}

Martin Bygate, Lancaster University, UK

Michael Carrier, The British Council

Charlotte Franson, Canterbury Christ Church

University, UK

Youping Han, CfBT Education Trust

Jennifer Jenkins, University of Southampton, UK

Richard M. Johnstone, University of Stirling, UK

David Little, University of Dublin, Ireland

\section{Advisory Board}

Marta Antón, Indiana University, USA

Larissa Aronin, Trinity College Dublin, Ireland

Anne Burns, Macquarie University, Australia

David Carless, University of Hong Kong

Jasone Cenoz, University of the Basque Country

Alexander Gilmore, University of Tokyo, Japan

Hossein Nassaji, University of British Columbia, Canada

Claire Kramsch, University of California, Berkeley, USA

Jo Lewkowicz, University of Warsaw, Poland
Ernesto Macaro, University of Oxford, UK Emma Marsden, University of York, UK Susan Maingay, King's College London, UK Florence Myles, University of Essex, UK Jenny Pugsley, Trinity College London, UK Keith Richards, University of Warwick, UK Rev. Lynda Taylor, University of Cambridge ESOL Examinations, UK

Alison Mackey, Ceorgetown University, USA Waldemar Martyniuk, ECML, Austria Nina Spada, OISE, University of Toronto, Canada Erwin Tschirner, Universität Leipzig, Germany Wang Qiang, Beijing Normal University, China T. Ruanni F. Tupas, National University of Singapore Cynthia White, Massey University, New Zealand Rosemary Wildsmith, University of Natal, South Africa

\section{Editorial correspondence}

Dr Graeme Porte editorlanguageteaching@gmail.com

Depto. de Filologías Inglesa y Alemana, Campus Cartuja, Universidad de Granada, 18071 Granada, España

copying

This journal is registered with the Copyright Clearance Center, 222 Rosewood Drive, Danvers, MA 01923. Organisations in the USA who are also registered with C.C.C. may therefore copy material (beyond the limits permitted by sections 107 and 108 of US copyright law) subject to payment to C.C.C. of the per-copy fee of $\$ 12.00$. This consent does not extend to multiple copying for promotional or commercial purposes. Code 0261-4448/2012.

Organisations authorised by the Copyright Licensing Agency may also copy material subject to the usual conditions. ISI Tear Sheet Service, 3501 Market Street, Philadelphia, Pennsylvania 19104, USA is authorised to supply single copies of separate articles for private use only.

For all other use, permission should be sought from the Cambridge or New York offices of the Cambridge University Press. Information on language teaching and all other Cambridge journals can be accessed via journals.cambridge.org

\section{Subscriptions}

The subscription price (which includes electronic access to institutional subscribers, but excludes VAT) of Volume 45, 2012, is $£ 182, \$ 308$ in USA, Canada and Mexico for institutions $£ 44, \$ 80$ in USA, Canada and Mexico for individuals when ordering direct from the Press and certifying that the journal is for their personal use. Single parts cost $£ 45, \$ 76$ in USA, Canada and Mexico plus postage.

The electronic-only price is available to institutional subscribers for $£ 153, \$ 266$ in USA, Canada and Mexico. Four issues of language teaching (ISSN 0261-4448) (published in January, April, July and October) form a volume. A complete volume may be purchased at the subscription price (which includes postage by air where appropriate) if payment is made before publication of the volume is complete.

Orders, which must be accompanied by payment, may be sent to a bookseller or to Cambridge University Press, The Edinburgh Building, Shaftesbury Road, Cambridge CB2 8RU or in the USA, Canada or Mexico, to Cambridge University Press, The Journals Fulfillment Department, 100 Brook Hill Drive, West Nyack, New York 10994-2133. EU subscribers (outside the UK) who are not registered for VAT should add VAT at their country's rate. VAT registered subscribers should provide their VAT registration number. Japanese prices for institutions (including ASP delivery) are available from Kinokuniya Company Ltd, P.0. Box 55, Chitose, Tokyo 156, Japan.

Periodicals postage paid at New York, NY and at additional mailing offices, POSTMASTER: send address changes in USA, Canada and Mexico to language teaching, Cambridge University Press, 100 Brook Hill Drive, West Nyack, New York 10994-2133.

The publisher has no responsibility for the persistence or accuracy of URLS for external or third-party internet websites referred to in this journal, and does not guarantee that any content on such websites is, or will remain, accurate or appropriate.

All URLS referenced in this journal were correct approximately two months before publication.

\section{Abstracting and indexing services}

IBZ International Bibliography of Periodical Literature; IBR International Bibliography of Book Reviews of Scholarly Literature; Periodicals Index Online; Linguistic Abstracts Online; British Education Index; ERIC (European Reference Index for the Humanities); Linguistics \& Language Behavior Abstracts; MLA International Bibliography; Bibliographie Moderner

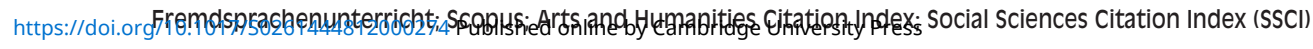

